\title{
Natural and anthropogenic variations in a channelized water course in Centre of Portugal
}

\author{
Pedro M. Silva-Santos ${ }^{1}$, Simone V. Oliveira², Rui M. V. Cortes², António C. Albuquerque ${ }^{3}$ \\ ${ }^{1}$ Lab. Ecologia Aplicada (LEA), Universidade de Tras-os-Montes e Alto Douro, Quinta de Prados, 5000- \\ 911, Vila Real, Portugal. Email: pedross@utad.pt \\ 2 Departamento Florestal, Universidade de Trás-os-Montes e Alto Douro, Quinta de Prados, 5000-102, Vila \\ Real, Portugal. Email: simonev@utad.pt,rcortes@utad.pt \\ 3 Departamento Engenharia Florestal, Instituto Superior de Agronomia, Tapada da Ajuda, 1349-017, \\ Lisboa, Portugal. Email: cdisa@isa.utl.pt
}

\begin{abstract}
The present study took place in the Mondego River, located in the Centre of Portugal. The lower sector of the river (Lower Mondego) is largely man-made due to regularization and rectification of the channel. The objective was to assess the impacts on the aquatic communities (fishes and benthic invertebrates). Fauna inventories were performed in June and September of 2000 and 2001 , together with habitat characterization. Three sampling sites were selected in this segment and compared to a reference site located upstream. It is concluded that the presence of structures such as submerged weirs and riprap, promoted the diversity, due to the physical complexity, which they introduced into the system. The dramatic flood peaks that occurred in the winter of 2000/01 also caused substantial changes in the fluvial dynamics and in the habitats: the large amount of suspended solids transported resulted in a riverbed of unstable fine materials, and in a subsequent biological impoverishment. However, both communities displayed a high resilience to these changes; the inter-annual differences being obscured by the seasonal ones on macroinvertebrate communities.
\end{abstract}

Keywords: benthic invertebrates, fishes, channelization, fluvial dynamics, floods.

\section{RESUMEN}

El presente trabajo tuvo lugar en el río Mondego, localizado en el Centro de Portugal. El tramo bajo del río (Bajo Mondego) se encuentra intensamente transformado debido al regularización y rectificación del cauce. El objetivo fue evaluar los impactos en las comunidades acuáticas (peces e invertebrados bentónicos). Se realizaron inventarios de fauna en Junio y Septiembre de 2000 y 2001, junto con la caracterización del hábitat. Se seleccionaron tres localidades en este segmento fluvial y se compararon con una localidad de referencia localizada aguas arriba. Se concluye que la presencia de varias estructuras como los azudes sumergidos y enrocamentos, promovió la diversidad, derivado de la complejidad fisica que ellos introdujeron en el sistema. Las riadas dramáticas que ocurrieron en el invierno de 2000/01 también causaron cambios sustanciales en la dinámica fluvial y en los hábitats: la gran cantidad de sólidos en suspensión transportada dio lugar a un substrato constituido por materiales finos inestables, y al empobrecimiento biológico consecuente. Sin embargo, ambas comunidades mostraron una elevada resiliencia a estos eventos, quedando las diferencias interanuales ocultadas por las diferencias estaciónales en las comunidades de invertebrados.

Palabras clave: invertebrados bentónicos, peces, canalización, dinámica fluvial, riadas.

\section{INTRODUCTION}

Unlike some other European countries such as Denmark and England (Brookes, 1988), Portugal has only few extensions of channelized river segments, most of which are set in urban environments (Aguiar et al., 2001). These segments are located on large floodplains, in order to maximi- ze crop production through irrigation. In these cases, the riverbed has been lowered, while riparian land is periodically cleared of trees and riverbank edges are cleaned (Aguiar et al., 2001).

The objectives of this study carried out in the terminal part of the Mondego River (Centre of Portugal) were to characterize the macroinvertebrate communities and fish (abundance and 
diversity) in different sectors of the river, comparing channelized segments with natural ones. An additional objective was to evaluate the effects of the floods that occurred during the study period (January of 2001) in these same sectors, and which caused a large impact on the river habitats. In channelized sectors, the influence of hydraulic structures on the diversity of organisms was also assessed.

\section{MATERIAL AND METHODS}

\section{Study area and channelization activities}

The Mondego River flows in an E-W direction from the "Serra da Estrela" mountains (1547 m) for about $227 \mathrm{~km}$ until "Figueira da Foz". The influence of the Atlantic increases the relative humidity of the air and affects temperatures and precipitation. The catchment area has $6671 \mathrm{~km}^{2}$ and a medium altitude of $375 \mathrm{~m}$, with a mean annual precipitation of $1130 \mathrm{~mm}$. We may divide the longitudinal profile into different segments, according to the morphometric characteristics. The segment located in the lowest part is called the Lower Mondego and is fully regulated and channelized. The Lower Mondego runs along an extensive alluvial plain of Cenozoic materials that extends from Coimbra to Figueira da Foz $(37.5 \mathrm{~km})$, with altitude levels between $0 \mathrm{~m}$ and $16 \mathrm{~m}$ (Vieira \& Ferreira, 1997).

The main purpose of the channelization of Lower Mondego was flood control (to a limit of $1200 \mathrm{~m}^{3} / \mathrm{s}$ for a recurrence period of 100 years) and the enlargement of the agricultural area. The design of an entirely new river channel was coupled with two dams upstream of Coimbra, to regulate the flows from the main river and the tributaries. Specifically the channelization of the Lower Mondego consisted in resection the riverbed and in the construction of extensive longitudinal dykes, constraining this river segment in a entirely new channel with artificial banks, trapezoidal shaped in cross section. Submerged weirs and riprap were also constructed to reduce the hydraulic energy, to settle the transported sediments and to stabilize the riverbanks.

In December and January of 2000/01 an extremely high precipitation in the NO and SE slopes of the basin occured. Cumulative precipitation for the two months registered return

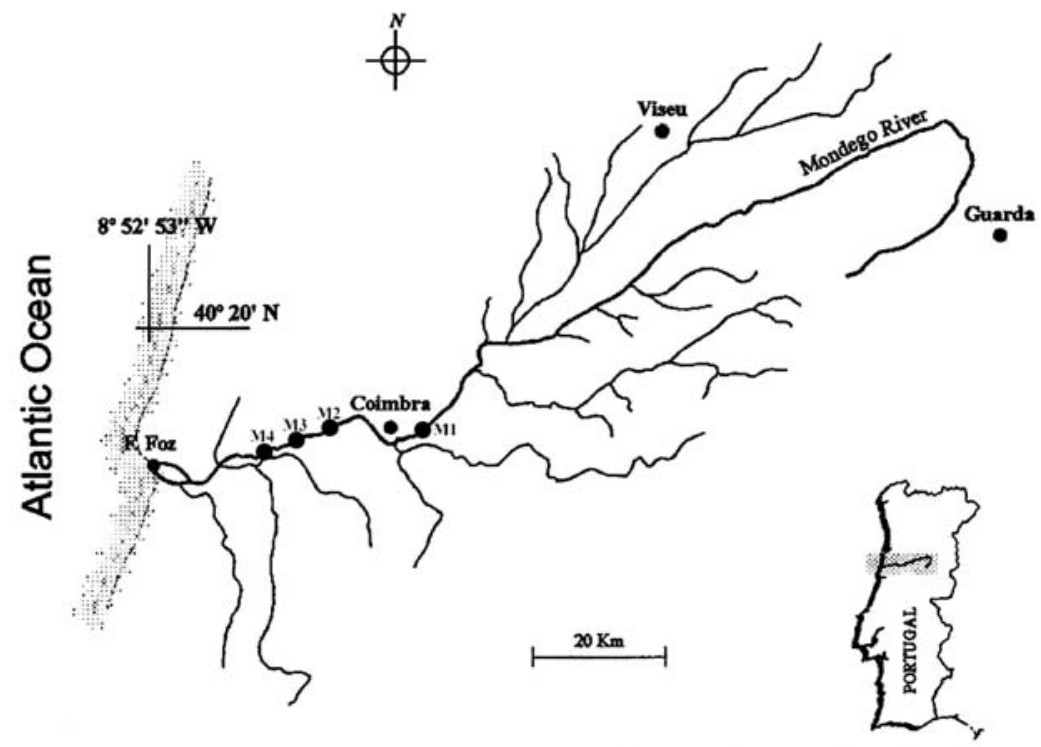

Figure 1. Location of the sampling sites within the Mondego Basin. M1- Reference site; M2, M3 and M4 - Sites on channelized sector. Localización de las estaciones de muestreo en la Cuenca de Mondego. M1-Localidad de referencia, M2, M3, M4 - localidades en el tramo canalizado. 
periods of 250 and 300 years respectively (Rodrigues et al., 2001). The high saturation level of the soil increased the superficial flow in the catchment, which exceeded the storage capacity of the reservoirs. Consequently, the flood events of January 26 and 27 caused the rupture of the dykes downstream of Coimbra.

\section{Sampling sites}

Three sampling sites were set in the regularized Central Bed of the Mondego River (M2, M3, M4), between Coimbra and the river mouth (Figueira da Foz), and one located approximately $14 \mathrm{Km}$ upstream of Coimbra (M1) - (Fig. 1). This last one, was a control site since it was not affected by channelization, although it is located approximately $20 \mathrm{Km}$ downstream of the Dam of Aguieira. This site has well developed riparian vegetation on the left bank. In contrast, the right bank presents scarce vegetation due to vegetation clear cutting and to the high deposition of materials (small stones, gravel and sand). The sites in the artificial segment exhibit extensive riprap along the banks, with constant slope of $45^{\circ}$, partially colonized by shrubs and trees (mainly Populus spp.). Medium fraction materials (stones and gravel) dominated the riverbed, but were replaced by a lower grain size fraction in the second part of the study after the flood events. M2 shows a semi-disaggregated submerged weir with resulting shear stress in the wet channel. A more detailed description of the different characteristics of each meso-habitat is in table 1.

Macroinvertebrate (M) and fish (F) sampling was carried out simultaneously in June (6) and September (9) of 2000 and 2001. Physical and chemical parameters (dissolved oxygen, $\mathrm{pH}$, temperature, conductivity, alkalinity and total suspended solids) were also analysed at the sampling sites for the same periods (Table 2).

\section{Benthic macroinvertebrates communities}

Benthic invertebrates were collected from reaches of approximately $100 \mathrm{~m}$ in length during a fixed time of 5 minutes (CPUE) by disturbing the substratum upstream of the net using a vigorous kicking and/or feet action. The sampling was performed using a $350 \mu \mathrm{m}$ mesh net with $600 \mathrm{~cm}^{2}$ aperture and embraced all the existent biotopes with an effort proportional to the relative importance of each habitat (Table 1). The nets were washed carefully between collections. The contents of the hand-net were placed in labeled containers, transported to the laboratory, and the specimens sorted alive. For preservation $70 \%$ ethanol was used for subsequent identification. Wherever possible, identification was done to species level using the available keys (except Diptera and Oligochaeta).

\section{Ichthyic communities}

In contrast with benthic collections, fish sampling allowed the discrimination between habitat types in order to detect the influence of hydraulic structures and erosion sedimentation processes (Table 1). Fish were captured using an Electrocatch apparatus, model WFC7-HV, powered by a generator (Honda GX160) of 4.0 KW. Electrofishing used DC current and the voltage was set between 150 to $200 \mathrm{~V}$ in order to produce a current from 2.5 to $4 \mathrm{~A}$. This fact, together with a constant capture effort of 7 minutes in each meso-habitat (CPUE), allowed comparable results among the different inventoried habitat types. Electrofishing captures were complemented by $30 \times 2.5 \mathrm{~m}$ static multimesh gill net (mesh types: $32 \mathrm{~mm}, 43 \mathrm{~mm}, 50 \mathrm{~mm}, 65$ $\mathrm{mm}$ and $85 \mathrm{~mm}$ ), which was placed in the deeper pools for 3-4 hours.

\section{Data treatment}

To compare sites and periods for both sampled communities, the total number of individuals and Shannon diversity index were computed through PRIMER 5.2.2 (Clarke \& Gorley, 2001).

Multivariate methods were used to detect the spatial and temporal patterns underlying the biotic and abiotic data. Metric Dimensional Analysis (MDS) was used through the package SYN-TAX 2000 (Podani, 2001) and non-Metric 
Table 1. Characterization of habitats in each sampled site and aquatic communities that were inventoried in each sector: $\mathrm{F}-$ fishes; $\mathrm{M}-$ macroinvertebrates. Example: M1006 means reference site (M1) sampled in 2000 (second and third code's cypher) in June (fourth code's cypher). The last code refers to habitat type: D- right bank; E- left bank; T- submersed weirs; R- nets; N- rip rap; I- sand bank. Caracterización de hábitats en cada localidad y las comunidades acuáticas que se inventariaron en cada sector. Ejemplo: M1006 significa que se trata de la estación de referencia (M1), muestreada en el año 2000 (segunda y tercera cifra del código) en el mes de Junio (cuarta cifra del código). La última cifra del código designa el hábitat: $D$ - margen derecha; E- margen izquierda; $T$ - azude sumergido; $R$ - redes; $N$ - enrocamento; $I$ - banco de arena.

\begin{tabular}{|c|c|c|c|c|c|}
\hline Habitat & $\begin{array}{c}\text { Mean } \\
\text { depth }(m)\end{array}$ & $\begin{array}{l}\text { Dominant } \\
\text { substrate }\end{array}$ & $\begin{array}{c}\text { Current } \\
\left(\mathrm{m} \mathrm{s}^{-1}\right)\end{array}$ & Bank structure & Communities \\
\hline M1006D & 1.20 & \multirow{7}{*}{ Stones } & 0.28 & Natural, smooth profile with tree clumps. & $\mathrm{F} ; \mathrm{M}$ \\
\hline M1009D & 1.20 & & 0.28 & Natural, smooth profile with tree clumps. & $\mathrm{F} ; \mathrm{M}$ \\
\hline M1009E & 2.50 & & 0.28 & Natural with a vertical profile. Riparian vegetation without interruptions. & $\mathrm{F}$ \\
\hline M1016D & 1.20 & & 0.28 & Natural, smooth profile with tree clumps. & $\mathrm{F} ; \mathrm{M}$ \\
\hline M1016E & 2.50 & & 0.28 & Natural with a vertical profile. Riparian vegetation without interruptions. & $\mathrm{F}$ \\
\hline M1019D & 1.20 & & 0.28 & Natural, smooth profile with tree clumps. & $\mathrm{F} ; \mathrm{M}$ \\
\hline M1019E & 2.50 & & 0.28 & Natural with a vertical profile. Riparian vegetation without interruptions. & $\mathrm{F}$ \\
\hline M2006E & 0.50 & Gravel & 0.20 & Artificial embankment. $45^{\circ}$ slope. Dense riparian vegetation. & $\mathrm{F} ; \mathrm{M}$ \\
\hline M2006T & 0.40 & Stones & 0.84 & Semi-disintegrated submersed weir with stone blocks. & $\mathrm{F}$ \\
\hline M2006R & 2.50 & Gravel & 1.05 & & $\mathrm{~F}$ \\
\hline M2009T & 0.40 & Stones & 0.84 & Semi-disaggregated submersed weir with stone blocks. & $\mathrm{F}$ \\
\hline M2009E & 0.50 & Gravel & 0.20 & Artificial embankment. $45^{\circ}$ slope. Dense riparian vegetation. & $\mathrm{F} ; \mathrm{M}$ \\
\hline M2016E & 0.50 & Gravel & 0.20 & Artificial embankment. $45^{\circ}$ slope. Dense riparian vegetation. & $\mathrm{F} ; \mathrm{M}$ \\
\hline M2016T & 0.40 & Stones & 0.84 & Semi-disaggregated submersed weir with stone blocks. & $\mathrm{F}$ \\
\hline M2016R & 2.50 & Gravel & 0.95 & & $\mathrm{~F}$ \\
\hline M2019E & 0.50 & Gravel & 0.20 & Artificial embankment. $45^{\circ}$ slope. Dense riparian vegetation. & $\mathrm{F} ; \mathrm{M}$ \\
\hline M2019T & 0.40 & Stones & 0.84 & Semi-disaggregated submersed weir with stone blocks. & $\mathrm{F}$ \\
\hline M2019R & 2.50 & Gravel & 1.02 & & $\mathrm{~F}$ \\
\hline M3006D & 1.20 & Stones & 0.15 & Artificial embankment. $45^{\circ}$ slope. Riparian vegetation with interruptions. & $\mathrm{F}$ \\
\hline $\mathrm{M} 3006 \mathrm{~N}$ & 0.60 & Stones & 0.25 & Rip rap with stone blocks. & $\mathrm{F}$ \\
\hline M3006R & 2.00 & Gravel & 0.55 & & $\mathrm{~F}$ \\
\hline M3009D & 1.20 & Stones & 0.15 & Artificial embankment. $45^{\circ}$ slope. Riparian vegetation with interruptions. & $\mathrm{F} ; \mathrm{M}$ \\
\hline $\mathrm{M} 3009 \mathrm{~N}$ & 0.60 & Stones & 0.25 & Rip rap with stone blocks. & $\mathrm{F}$ \\
\hline M3016D & 1.20 & Stones & 0.15 & Artificial embankment. $45^{\circ}$ slope. Riparian vegetation with interruptions. & $\mathrm{F} ; \mathrm{M}$ \\
\hline $\mathrm{M} 3016 \mathrm{~N}$ & 0.60 & Stones & 0.25 & Rip rap with stone blocks. & $\mathrm{F}$ \\
\hline M3016R & 2.00 & Gravel & 0.49 & & $\mathrm{~F}$ \\
\hline M3019D & 1.20 & Stones & 0.15 & Artificial embankment. $45^{\circ}$ slope. Riparian vegetation with interruptions. & $\mathrm{F} ; \mathrm{M}$ \\
\hline M3019N & 0.60 & Stones & 0.25 & Rip rap with stone blocks. & $\mathrm{F}$ \\
\hline M3019R & 2.00 & Gravel & 0.54 & & $\mathrm{~F}$ \\
\hline M4006E & 0.70 & Sand & 0.06 & Sand bank with herbaceous vegetation. & $\mathrm{F} ; \mathrm{M}$ \\
\hline M4006I & 1.00 & Sand & 0.10 & Stabilized sand bank with herbaceous and shrubby vegetation. & $\mathrm{F}$ \\
\hline M4006D & 1.50 & Stones & 0.06 & Artificial embankment. Riparian vegetation with interruptions. & $\mathrm{F}$ \\
\hline M4006R & 2.50 & Sand & 0.10 & & $\mathrm{~F}$ \\
\hline M4009D & 1.50 & Stones & 0.06 & Artificial embankment. Riparian vegetation with interruptions. & $\mathrm{F}$ \\
\hline $\mathrm{M} 4009 \mathrm{E}$ & 0.70 & Sand & 0.06 & Sand bank with herbaceous vegetation. & $\mathrm{F} ; \mathrm{M}$ \\
\hline M4009I & 1.00 & Sand & 0.10 & Banco de areia estabilizado com vegetação herbácea & $\mathrm{F}$ \\
\hline M4016D & 1.50 & Stones & 0.06 & Artificial embankment. Riparian vegetation with interruptions. & $\mathrm{F}$ \\
\hline $\mathrm{M} 4016 \mathrm{E}$ & 0.70 & Sand & 0.06 & Sand bank with herbaceous vegetation. & $\mathrm{F} ; \mathrm{M}$ \\
\hline M4016R & 2.50 & Sand & 0.15 & & $\mathrm{~F}$ \\
\hline M4019D & 1.50 & Stones & 0.06 & Artificial embankment. Riparian vegetation with interruptions. & $\mathrm{F}$ \\
\hline M4019I & 1.00 & Sand & 0.10 & Sand bank with herbaceous vegetation. & $\mathrm{F}$ \\
\hline M4019E & 0.70 & Sand & 0.06 & Sand bank with herbaceous vegetation. & $\mathrm{F} ; \mathrm{M}$ \\
\hline M4019R & 2.50 & Sand & 0.16 & & $\mathrm{~F}$ \\
\hline
\end{tabular}


Table 2. Physical and chemical parameters at the 4 sampling sites in June/September 2000 and 2001. Parámetros físicos y químicos a las 4 localidades en 2000 y 2001 (Junio/Septiembre).

\begin{tabular}{|c|c|c|c|c|c|c|}
\hline Sampling site & D.O. $\left(\mathrm{mg} \cdot \mathrm{L}^{-1}\right)$ & $\mathbf{p H}$ & Temp. $\left({ }^{\circ} \mathrm{C}\right)$ & Cond. $\left(\mu S \cdot \mathrm{cm}^{-1}\right)$ & Alkalinity $\left(\mathrm{mg} \cdot \mathrm{L}^{-1} \mathrm{CaCO}_{3}\right)$ & TSS $\left(\mathrm{mg} \cdot \mathrm{L}^{-1}\right)$ \\
\hline M1006 & 9.5 & 6.5 & 18.6 & 76.1 & 11.8 & 3 \\
\hline M1009 & 8.4 & 7.0 & 20.6 & 78.2 & 14.4 & 1 \\
\hline M1016 & 10.2 & 6.3 & 22.8 & 76.3 & 13.8 & 3 \\
\hline M1019 & 9.0 & 6.5 & 22.4 & 79.8 & 9.30 & 0 \\
\hline M2006 & 8.9 & 6.7 & 21.1 & 120.1 & 22.9 & 5 \\
\hline M2009 & 9.1 & 7.6 & 23.4 & 103.0 & 20.5 & 1 \\
\hline M2016 & 6.7 & 6.4 & 22.1 & 128.9 & 26.4 & 8 \\
\hline M2019 & 7.0 & 7.0 & 22.3 & 113.0 & 18.3 & 8 \\
\hline M3006 & 8.6 & 7.4 & 25.5 & 123.5 & 24.8 & 8 \\
\hline M3009 & 10.2 & 7.7 & 24.3 & 149.0 & 27.7 & 2 \\
\hline M3016 & 10.4 & 8.1 & 29.0 & 136.7 & 31.9 & 8 \\
\hline M3019 & 9.6 & 7.3 & 25.0 & 120.9 & 19.8 & 5 \\
\hline M4006 & 9.2 & 6.9 & 23.9 & 149.0 & 31.8 & 7 \\
\hline M4009 & 6.6 & 6.6 & 22.4 & 137.0 & 35.4 & 2 \\
\hline M4016 & 10.4 & 8.1 & 24.9 & 161.0 & 40.1 & 20 \\
\hline M4019 & 7.9 & 7.2 & 23.8 & 129.0 & 20.9 & 20 \\
\hline
\end{tabular}

Dimensional Analysis (n-MDS) through PRIMER 5.2.2 (Clarke \& Gorley, 2001). N-MDS operated on a sample similarity matrix of the Bray-Curtis coefficient instead of the original data matrix, converting the similarity values to rank order (in order to preserve the original relationships between samples). MDS is a rela- ted technique, in the sense that it also uses a distance or dissimilarity matrix but, on the contrary, assumes the existence of linear relationships between variables.

The data files were not transformed to enhance the effect of the density variation of organisms among sites.

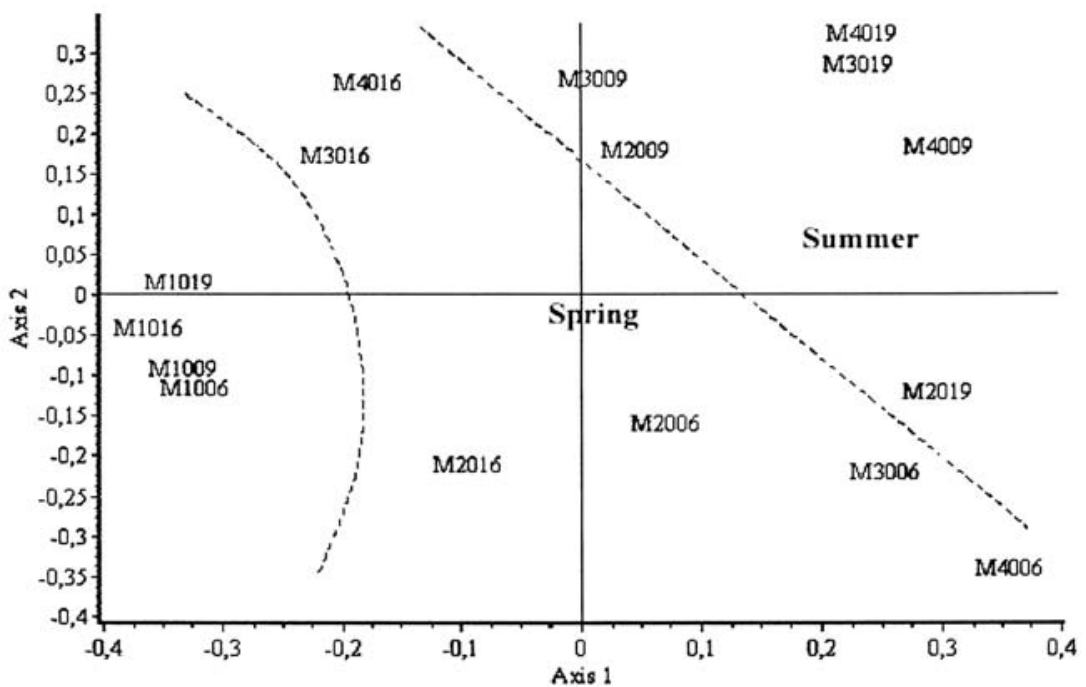

Figure 2. MDS ordination of sampling sites based on benthic invertebrates. Example: M1006 means reference site (M1) sampled in 2000 (second and third code's cypher) in June (last code's cypher). Ordenación por MDS de las estaciones de muestreo con base en los invertebrados bentónicos. Ejemplo: M1006 significa que se trata de la estación de referencia (M1), muestreada en el año 2000 (segunda y tercera cifra del código) en el mes de Junio (última cifra del código). 


\section{RESULTS}

\section{Macroinvertebrates communities}

The differences between the reference site and the channelized sector and the potential effects of the floods in the macroinvertebrate communities were assessed through MDS ordinations of sampling sites. Figure 2 shows a clear separation of the reference site (M1) relative to the channelized ones. This site presents then, a specific benthic assemblage, characterized by different caddisflies (Polycentropus sp., Plectrocnemia sp., Tinodes waeneri) and stoneflies (Leuctra fusca) taxa. On the contrary, some Heteroptera (e.g.: Gerris lateralis and Micronecta sp.) show a preference for the modified sector. A clear seasonal separation of the sampling sites is another important aspect displayed by figure 2 . This fact demonstrates the high capacity of recovery of the system since inter-annual differences are obscured by seasonal ones. The importance of riverbed materials in explaining the dynamics of benthic assemblages is illustrated by figure 3 . Here, we can link these changes to the winter peak flows, which cause an extensive deposition of fine sediments, especially clear in site M2.

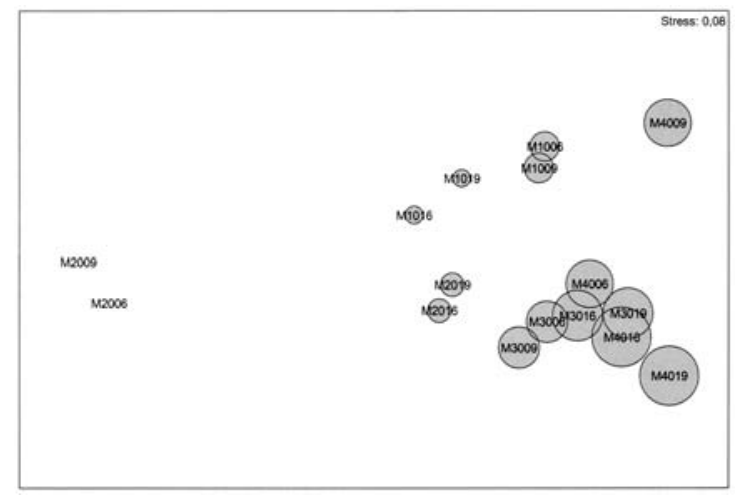

Figure 3. n-MDS ordination of sampling sites based on benthic fauna. In each site was overlapped one circle with proportional radius at relative importance of the sand on the substrate. Abbreviations of the sampling sites are given in figure 2 . Ordenación n-MDS de las estaciones de muestra con base en la fauna bentónica. Sobre cada estación se instaló un círculo de radio proporcional a la importancia relativa de arena en el substrato. Las abreviaciones de las localidades de muestreo están en la figura 2.
Table 3. Total individuals and Shannon's diversity index for macroinvertebrate communities of the 4 sampling sites in 2000 and 2001 (June/September). Total de individuos y el Índice de diversidad de Shannon para las comunidades de macroinvertebrados de las 4 localidades en 2000 y 2001 (Junio/Septiembre).

\begin{tabular}{lccc}
\hline \multicolumn{2}{c}{ Sampling sites } & $\begin{array}{c}\text { Total } \\
\text { individuals }\end{array}$ & $\begin{array}{c}\text { Shannon's } \\
\text { diversity }\end{array}$ \\
\hline \multirow{2}{*}{ M1 } & 2000 & $324 / 385$ & $1.99 / 2.54$ \\
& 2001 & $338 / 486$ & $1.83 / 1.93$ \\
M2 & 2000 & $1615 / 491$ & $2.81 / 1.93$ \\
& 2001 & $680 / 4661$ & $2.14 / 1.44$ \\
M3 & 2000 & $978 / 155$ & $0.84 / 1.23$ \\
& 2001 & $305 / 1276$ & $2.59 / 2.50$ \\
M4 & 2000 & $4334 / 2326$ & $1.50 / 1.44$ \\
& 2001 & $293 / 830$ & $2.02 / 2.24$ \\
\hline
\end{tabular}

The reduced stress value obtained by the n-MDS ordination (0.08) demonstrates a good representation of the global variance.

In the reference site the diversity of benthic organisms was, in general, superior when compared to the channelized sites before the flood events. After this phenomenon, diversity decreased in the reference site, while the total number of individuals did not suffer great variations. However, in the channelized sites (M2, M3 and M4), the extreme flows were probably responsible for the drastic reduction in invertebrate abundances, as shown in Table 3. Nevertheless, the diversity was not substantially changed in these sites.

A taxonomic list of macroinvertebrates determined in the sampling sites is shown in Annex 1.

\section{Ichthyic communities}

A total of thirteen taxa, of which six were cyprinids, were recorded (Table 4). This family, besides barbel (Barbus bocagei), includes three Iberian endemisms (Iberian nase - Chondrostoma polylepis, Portuguese roach - Rutilus macrolepidotus, chub - Squalius carolitertii), and two introduced species (goldfish Carassius auratus, gudgeon - Gobio gobio). Cobitis paludica was also recorded. Aside from these, two other exotic species were recorded: eastern mosquitofish (Gambusia holbrooki), 
Table 4. List of ichthyic species captured in the sampling sites in 2000 (00) and 2001 (01) in June (6) and September (9). Lista de especies de peces capturados en las localidades en 2000 (00) y 2001 (01) en Junio (6) y Septiembre (9).

Specie

M1006 M1009 M1016 M1019 M2006 M2009 M2016 M2019 M3006 M3009 M3016 M3019 M4006 M4009 M4016 M4019

\begin{tabular}{lrrrrrrrrrrrrrrrrr}
\hline Alosa fallax & 0 & 0 & 0 & 0 & 0 & 0 & 1 & 0 & 0 & 0 & 0 & 0 & 3 & 0 & 1 & 0 \\
Anguilla anguilla & 0 & 8 & 0 & 0 & 7 & 9 & 5 & 7 & 4 & 8 & 12 & 7 & 11 & 2 & 1 & 10 \\
Barbus bocagei & 0 & 2 & 5 & 6 & 56 & 39 & 63 & 55 & 29 & 1 & 12 & 40 & 16 & 34 & 21 & 31 \\
Carassius auratus & 0 & 0 & 0 & 0 & 0 & 0 & 0 & 0 & 0 & 0 & 1 & 1 & 0 & 0 & 2 & 1 \\
Chondrostoma polylepis & 0 & 5 & 30 & 50 & 14 & 3 & 25 & 29 & 12 & 6 & 9 & 8 & 5 & 1 & 4 & 2 \\
Cobitis paludica & 4 & 2 & 4 & 1 & 13 & 2 & 12 & 3 & 11 & 4 & 8 & 0 & 39 & 2 & 2 & 2 \\
Gambusia holbrooki & 0 & 0 & 0 & 0 & 0 & 0 & 0 & 0 & 0 & 0 & 2 & 0 & 2 & 1 & 0 & 3 \\
Gobio gobio & 3 & 14 & 16 & 13 & 13 & 0 & 0 & 5 & 2 & 4 & 0 & 5 & 10 & 4 & 0 & 9 \\
Lepomis gibbosus & 1 & 1 & 1 & 5 & 0 & 1 & 0 & 1 & 0 & 3 & 1 & 2 & 2 & 4 & 3 & 1 \\
Squalius carolitertii & 12 & 13 & 2 & 0 & 0 & 0 & 0 & 0 & 1 & 0 & 1 & 1 & 0 & 2 & 0 & 1 \\
Liza ramada & 0 & 0 & 0 & 0 & 1 & 0 & 5 & 9 & 5 & 2 & 15 & 1 & 6 & 1 & 1 & 0 \\
Petromyzon marinus & 0 & 0 & 0 & 0 & 0 & 0 & 0 & 2 & 0 & 0 & 0 & 2 & 0 & 0 & 1 & 1 \\
Rutilus macrolepidotus & 29 & 8 & 27 & 52 & 2 & 1 & 0 & 0 & 3 & 2 & 0 & 4 & 0 & 0 & 0 & 0 \\
\hline & & & & & & & & & & & & &
\end{tabular}

Table 5. Total individuals and Shannon's diversity index for ichthyic communities of the meso-habitats inside the 4 sampling sites in 2000 and 2001 (June/September). Total de individuos y el Índice de diversidad de Shannon para las comunidades de peces en los mesohábitats de cada una de las 4 localidades en 2000 y 2001 (Junio/Septiembre).

\begin{tabular}{|c|c|c|c|c|}
\hline & \multicolumn{2}{|c|}{ Sampling sites } & \multirow{2}{*}{$\begin{array}{c}\begin{array}{c}\text { Total } \\
\text { individuals }\end{array} \\
49 / 18 \\
-/ 35\end{array}$} & \multirow{2}{*}{$\begin{array}{c}\begin{array}{c}\text { Shannon's } \\
\text { diversity }\end{array} \\
1.11 / 1.66 \\
-/ 1.48\end{array}$} \\
\hline & 2000 & $\begin{array}{l}\mathrm{D} \\
\mathrm{E}\end{array}$ & & \\
\hline & 2001 & $\begin{array}{l}\mathrm{D} \\
\mathrm{E}\end{array}$ & $\begin{array}{l}29 / 72 \\
56 / 55\end{array}$ & $\begin{array}{l}1.33 / 1.02 \\
1.37 / 1.02\end{array}$ \\
\hline \multirow{2}{*}{ M2 } & 2000 & $\begin{array}{l}\mathrm{E} \\
\mathrm{T} \\
\mathrm{R}\end{array}$ & $\begin{array}{c}15 / 18 \\
67 / 37 \\
24 /-\end{array}$ & $\begin{array}{c}1.46 / 1.13 \\
1.23 / 0.61 \\
0.83 /-\end{array}$ \\
\hline & 2001 & $\begin{array}{l}\mathrm{E} \\
\mathrm{T} \\
\mathrm{R}\end{array}$ & $\begin{array}{l}16 / 23 \\
55 / 61 \\
40 / 27\end{array}$ & $\begin{array}{l}0.70 / 1.75 \\
0.57 / 0.94 \\
1.08 / 1.07\end{array}$ \\
\hline \multirow{2}{*}{ M3 } & 2000 & $\begin{array}{l}\mathrm{N} \\
\mathrm{D} \\
\mathrm{R}\end{array}$ & $\begin{array}{c}10 / 19 \\
26 / 11 \\
31 /-\end{array}$ & $\begin{array}{c}1.28 / 1.65 \\
1.23 / 1.47 \\
1.12 /-\end{array}$ \\
\hline & 2001 & $\begin{array}{l}\mathrm{N} \\
\mathrm{D} \\
\mathrm{R}\end{array}$ & $\begin{array}{c}29 / 25 \\
8 / 37 \\
24 / 9\end{array}$ & $\begin{array}{l}1.72 / 1.83 \\
0.97 / 1.05 \\
1.01 / 0.96\end{array}$ \\
\hline \multirow{2}{*}{ M4 } & 2000 & $\begin{array}{l}\mathrm{E} \\
\mathrm{D} \\
\mathrm{I} \\
\mathrm{R}\end{array}$ & $\begin{array}{c}19 / 13 \\
21 / 26 \\
30 / 12 \\
24 /-\end{array}$ & $\begin{array}{c}0.63 / 1.78 \\
1.22 / 0.48 \\
0.77 / 0.87 \\
1.30 /-\end{array}$ \\
\hline & 2001 & $\begin{array}{l}\text { E } \\
D \\
\text { R } \\
\text { I }\end{array}$ & $\begin{array}{l}17 / 23 \\
8 / 22 \\
11 / 6 \\
-/ 10\end{array}$ & $\begin{array}{c}1.81 / 1.63 \\
0 / 0.66 \\
0.89 / 1.24 \\
-/ 0.90\end{array}$ \\
\hline
\end{tabular}

and the centrarchid pumpkinseed (Lepomis gibbosus). The migratory diadromous fish species identified were the anadromous sea lamprey (Petromyzon marinus), the twaite shad (Alosa fallax), the catadromous European eel (Anguilla anguilla), and the thinlip mullet (Liza ramada).

The influence of floods and channelization on the abundance and diversity of ichthyic communities was not conclusive (Table 5). However, figure 4 suggests that the two types of sites (channelized versus non-channelized) support different communities. In fact, Rutilus macrolepidotus, Gobio gobio and Squalius carolitertii are more represented in the reference site, whereas Barbus bocagei and Chondrostoma polylepis are common in both sectors (channelized/ non-channelized). The other species (including the exotic ones) are restricted to the artificial segment of the Mondego. The fish populations were discriminated by the meso-habitat in each station, which is also represented in figure 4. We may conclude from this the lack of inter-annual differences, demonstrating a high resilience of fish populations to extreme hydrological events. It is also possible to see from this figure and from Table 5 that a higher number of species exhibit preferences for the meso-habitats $\mathrm{T}$ and $\mathrm{N}$ (submerged weir and riprap, respectively). Similarly, a higher density of the majority of species is observed precisely in these habitats. 


\section{DISCUSSION}

An entire new channel in the Lower Mondego, after dredging and re-sectioning the old one, and transforming the natural banks in extensive dykes covered by riprap, affected the heterogeneity of habitats with repercussions on different fish and benthic composition, and had a detrimental effect on species diversity (Ward \& Stanford, 1983; Cortes et al., 2002).

The lack of intolerant species (with high oxygen and low levels of nutrient requirements) in artificialized sectors was filled by benthic communities with short life cycles (e.g. Gastropoda and Diptera) which can be explained by the reduction of available or suitable habitat, especially when the channel reflects hydro-geomorphic changes as pointed out by Maitland (1990) and Erskine et al. (1999). As seen in Englund \& Malqvist (1996), in similar artificial segments, the most modified habitats are the lotic ones.
Therefore, there is a more intense constancy of environmental conditions, especially associated with a regular flow along the longitudinal axis of the river and a lower range size of the substrate.

Infrequent events, which are regarded as being catastrophic because of their immediate effects on ecosystems or on human activity, are capable of leaving long-lasting traces. In this respect they can affect the organization and composition of the patchwork (Bravard \& Gilvear, 1996). However strong the disturbances are, flood "scars" generally heal quickly; major floods do not disturb the structure and functioning of the patchwork (Bravard \& Gilvear, 1996). The most impressive aspect of the effects of floods on aquatic insects is not the devastation of the fauna that results, but rather the remarkable ability of species to recover from such severe perturbations (Ward, 1992). The floods that happened in the winter of 2000/01 caused substantial alterations in the

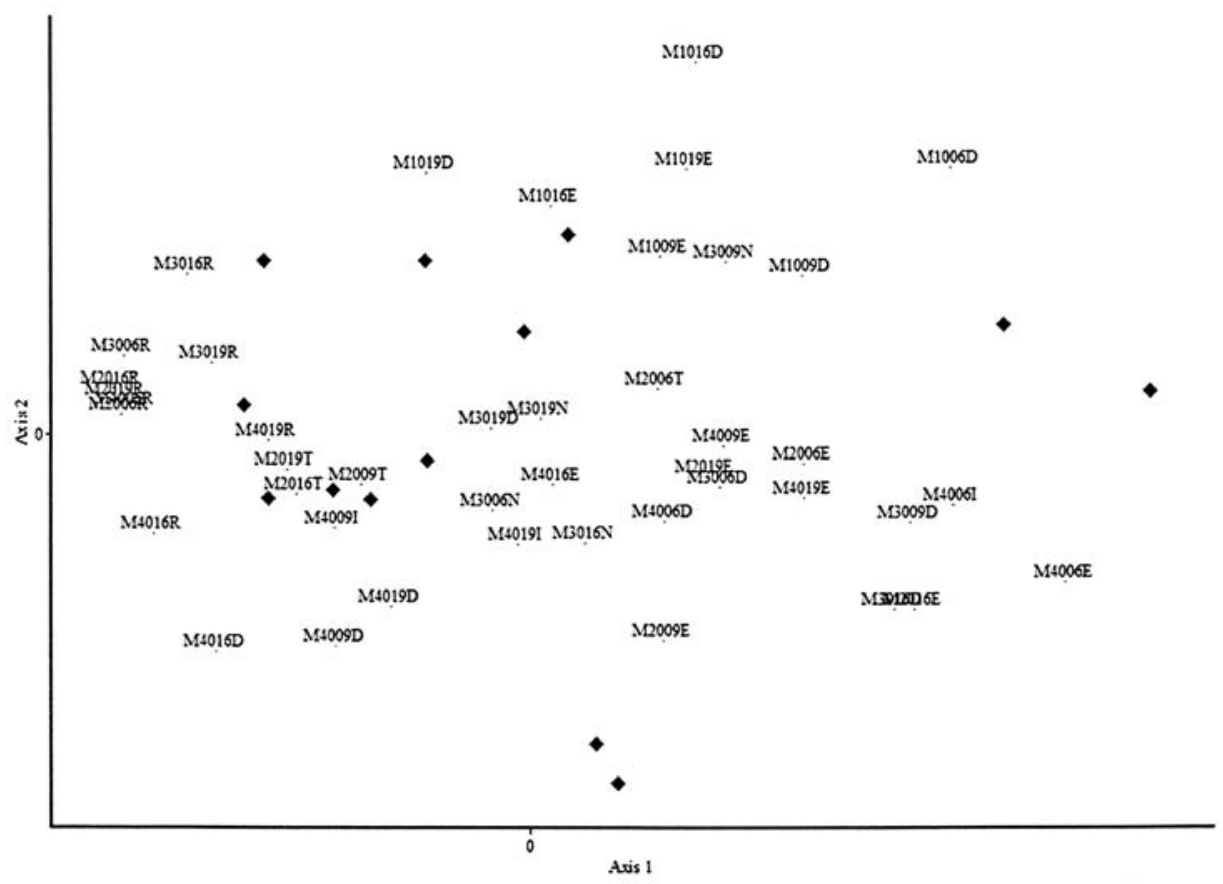

Figure 4. MDS ordination of sampling sites and habitats based on ichthyic communities. Symbols represent fish species. Abbreviations of the sampling sites are given in figure 2. The last code refers to habitat type (D - right bank, E - left bank, T - submersed weirs, N - rip rap, R - nets; I - sand bank). Ordenación MDS de las estaciones y respectivos habitats con base en las comunidades de peces. Los símbolos representan cada especie. Las abreviaciones de las localidades de muestreo están en la figura 2. La última cifra del código designa el hábitat: D- margen derecha; E- margen izquierda; $T$ - azude sumergido; $R$ - redes; $N$ enrocamento; I- banco de arena. 
fluvial dynamics. The elevated transport of solid material originated a strong sedimentation of unstable fine materials, leading to a biological impoverishment and alterations in the functioning of the system. Macroinvertebrate communities underwent a substantial reduction of abundance, with larger incidence in channelized sectors, where sedimentation was higher. Nevertheless, despite the floods, macroinvertebrate communities displayed a high resilience. Identical results were obtained by Ortega et al. (1991) after a flood in the basin of River Segura (Spain). The resilience of the benthic community is not, however, so surprising if we take into account that floods are natural phenomena that have occurred throughout the evolutionary history of aquatic insects (Ward, 1992). Macroinvertebrates respond to spatial and temporal variability by changes in the structure of their communities. They show tremendous diversity in their life history patterns, including variation in life cycle length, developmental strategies, and seasonality of the various life history stages (Greenwood \& Richardot-Coulet, 1996). Such traits explain also the seasonal variations, which were very clear in the Lower Mondego, probably because in changing environments there is a dominance of short-lived species (Hershey \& Lamberti, 1998).

The ichthyic communities did not show clear inter-annual or seasonal differences; moreover, the natural hydrological disturbances seemed to produce a low impact. Roux \& Copp (1996) argue that the importance of hydrological variation is necessary to complete the biological cycles and that only frequent flow peaks disrupt these communities.

Channelization of river courses, because of simplification of the channel environment, leads to a decrease in microhabitats, therefore mitigation structures providing habitat heterogeneity must be installed immediately after channelization (Brookes, 1988; Armitage, 1995). Submersed weirs diversify the habitat by impounding a greater depth of water above the structure, and by increasing the velocity downstream to erode a scour pool (Brookes, 1988). Other struc- tures built to absorb fluvial erosion such as brushing, logwalling, rock riprap, etc., may create specific habitats propitiating larger faunal diversity, due to the physical heterogeneity that is associated with them (Torre, 2001). For instance, Reeves et al. (1998) in a small stream in western Oregon observed abundance increases of dace with increasing levels of habitat complexity. Likewise, Vieira \& Ferreira (1997) argue that the use of submersed weirs and riprap in the Lower Mondego was environmentally positive. All these mitigation structures in channelized reaches increase the heterogeneity of available habitats for the aquatic communities and have been applied to restore streams all over Europe (Nijland \& Cals, 2000). In the present case we can assess the positive effects of submersed weir and riprap in improving the habitat, with consequences on diversity of fish populations.

\section{BIBLIOGRAPHY}

AGUIAR, F. C., M.T. FERREIRA \& I. MOREIRA. 2001. Exotic and native vegetation establishment following channelization of a western iberian river. Regulated Rivers: Research \& Management, 17: 509-526.

ARMITAGE, P. D. 1995. Faunal community change in response to flow manipulation. In: The Ecological Basis for River Management. D. M. Harper \& A. J. D. Ferguson (eds): 59-80. John Wiley \& Sons, London.

BRAVARD, J. P. \& D. J. GILVEAR. 1996. Hydrological and geomorphological structure of hydrosystems. In: Fluvial Hydrosystems. G. E. Petts \& C. Amoros (eds): 98-116. Chapman \& Hall, London.

BROOKES, A. 1988. Channelized Rivers: Perspectives for Environmental Management. John Wiley \& Sons Ltd: Chichester.

CLARKE, K. R. \& R. N. GORLEY. 2001. PRIMER v5, User Manual/Tutorial. [Computer program manual]. PRIMER-E Ltd.

CORTES, R. M. V., M. T. FERREIRA, S. V. OLIVEIRA \& D. OLIVEIRA. 2002. Macroinvertebrate community structure in a regulated river segment with different flow conditions. River Research and Applications, 18: 367-382. 
ENGLUND, G. \& D. MALQVIST. 1996. Effects of flow regulated, habitat area and isolation on the macroinvertebrate fauna of rapids in North Swedish rivers. Regulated Rivers: Research and Management, 12: 433-445.

ERSKINE, W. D., N. TERRAZOLO \& R. F. WARNER. 1999. River rehabilitation from the hydrogeomorphic impacts of a large hydro-electric power project: Snowy river, Australia. Regulated Rivers: Research and Management, 15: 3-24.

GREENWOOD, M. T. \& M. RICHARDOT-COULET. 1996. Aquatic invertebrates. In: Fluvial Hydrosystems. G. E. Petts \& C. Amoros (eds): 137-166. Chapman \& Hall, London.

HERSHEY, A. E. \& G. A. LAMBERTI. 1998. Stream macroinvertebrate communities. In: River ecology and management: lessons from the Pacific coastal ecoregion. R. J. Naiman \& R. E. Bilby (eds): 169-199. Springer-Verlag, New York.

MAITLAND, P. S. 1990. Biology of Fresh Waters: Terciary level biology. $2^{\text {ond }}$ ed. UK: Blackie Academic \& Professional.

MERRIT, R. W. \& K. W. CUMMINS. 1984. An introduction to the aquatic insects of North America. $2^{\text {ond }}$ ed. Kendall/Hunt, U.S.A

NIJLAND, H. J. \& M. J. R. CALS. 2000. River restoration in Europe: Pratical Approaches. Conference on River Restoration. Institute for Inland Water Management and Waste Water Treatment/RIZA. Lelystad, The Netherlands.

ORTEGA, M., M. L. SUÁREZ, M. R. VIDALABARCA \& L. RAMÍREZ-DÍAZ. 1991. Aspectos dinámicos de la composición y estructura de la comunidad de invertebrados acuáticos de la Rambla del Moro después de una riada (Cuenca del Río Segura: SE de España). Limnetica, 7: 1124.

PODANI, J. 2001. SYN-TAX 2000. Computer Programs for Data Analysis in Ecology and Systematics. [User's Manual]. Budapest: Scientia Publishing.

REEVES, G. H., P. A. BISSON \& J. M. DAMBACHER. 1998. Fish communities. In: River ecology and management: Lessons from the Pacific coastal ecoregion. R. J. Naiman \& R. E. Bilby (eds): 200-234. Springer-Verlag, New York.

RODRIGUES, R., C. BRANDÃO \& J. P. COSTA. 2001. Hidrologia das cheias do Mondego de 26 e 27 de Janeiro de 2001. Direcção dos Serviços de Recursos Hídricos. [on line]. URL: http://snirh.inag.pt/snirh/estudos_proj/main_ nav_fr.html.

ROUX, A. L. \& G. H. COPP. 1996. Fish populations in rivers. In: Fluvial Hydrosystems. G. E. Petts \& C. Amoros (eds): 167-183. Chapman \& Hall, London.

TORRE, A. 2001. Stream Stabilisation. Water and Rivers Comission. Report RR 10.

VIEIRA, P. A. \& M. T. FERREIRA. 1997. "Impacte Ambiental das Obras de Regularização Fluvial do Baixo Mondego: Contributo para o seu Estudo". Anais do Instituto Superior de Agronomia.

WARD, J. V. \& J. A. STANFORD. 1983. The serial discontinuity concept of lotic ecosystems. In: Dynamics of Lotic Ecosystems. T. D. Fontaine \& S. M. Bartell (eds): 29-42. Ann Arbor Sciences, Ann Arbor, Michigan.

WARD, J. V. 1992. Aquatic Insect Ecology. Biology and habitat (v.1). John Wiley \& Sons, Inc. 
Annex 1. List of macroinvertebrates present in the sampling sites. Lista de invertebrados presentes en las localidades muestreadas.

Taxon

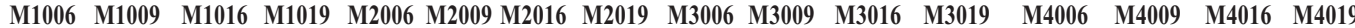

\begin{tabular}{lllllllllllllllllllllllllll}
\hline Hydracarina & 152 & 100 & 53 & 83 & 132 & 8 & 0 & 35 & 0 & 0 & 2 & 10 & 0 & 21 & 0 & 2
\end{tabular}

\section{Diptera}

Hemerodromia sp.

Ephydridae gen. sp.

Hydrellia sp.

Ephydra subocapa

Stratiomyidae gen. sp.

Tipula sp.

Tipula strepens

Dicranomyia sp.

Limnophora sp.

Atrichops sp.

Atherix sp.

Empididae gen. sp.

Chironomini gen. sp.

Tanypodinae gen. sp.

Orthocladiinae gen. sp.

Hemedromiinae gen. sp.

Dolichopodidae gen. sp.

Tipulidae gen. sp.

Limoniidae gen. sp.

Chironomus gr. plumosus 0

Simulium pseudequinum

Simulium

erythrocephalum

Simulium bezzii

Simulium sergenti

Simulium ruficorne

Simulium quadrifila

Sciomyzidae gen. sp.

Syrphus sp.

Sepedon tenuicornis

Sepedon sp.

Anthomyidae gen. sp.

Melanochelia riparia

Pericoma sp

Culicidae gen. sp.

Bezzia sp.

Dixella sp.

Atrichopogon sp.

Dimecoenia spinosa

$\begin{array}{rrrrrrrr}0 & 3 & 0 & 0 & 0 & 0 & 0 & 0 \\ 0 & 0 & 6 & 5 & 2 & 12 & 0 & 0 \\ 0 & 0 & 0 & 0 & 0 & 1 & 0 & 0 \\ 0 & 0 & 0 & 0 & 0 & 1 & 0 & 0 \\ 0 & 0 & 0 & 0 & 0 & 0 & 0 & 0 \\ 0 & 0 & 0 & 0 & 0 & 0 & 0 & 0 \\ 0 & 1 & 0 & 0 & 0 & 0 & 0 & 0 \\ 0 & 0 & 0 & 0 & 0 & 0 & 0 & 0 \\ 0 & 0 & 0 & 0 & 0 & 0 & 0 & 0 \\ 0 & 0 & 1 & 1 & 0 & 0 & 0 & 0 \\ 0 & 0 & 0 & 0 & 0 & 1 & 0 & 0 \\ 0 & 1 & 0 & 0 & 0 & 0 & 0 & 0 \\ 0 & 2 & 0 & 0 & 0 & 0 & 0 & 0 \\ 51 & 24 & 99 & 49 & 15 & 79 & 7 & 8 \\ 110 & 49 & 12 & 3 & 17 & 6 & 0 & 1 \\ 9 & 8 & 194 & 11 & 38 & 54 & 766 & 15 \\ 11 & 9 & 49 & 10 & 22 & 27 & 13 & 2 \\ 0 & 0 & 0 & 0 & 1 & 0 & 0 & 0 \\ 0 & 1 & 0 & 0 & 0 & 0 & 0 & 0 \\ 1 & 0 & 0 & 0 & 0 & 3 & 0 & 0 \\ 4 & 0 & 0 & 0 & 0 & 0 & 0 & 0 \\ 0 & 0 & 0 & 0 & 0 & 0 & 0 & 1 \\ 0 & 0 & 0 & 0 & 0 & 0 & 1 & 0 \\ 0 & 0 & 0 & 0 & 0 & 10 & 0 & 0\end{array}$

0
0
0
0
0
0
0
0
0
0
0
0
0
32
15
16
100
0
0
0
0
0
0
0
0
0
0
0
0
0
0
0
0
0
0
0
0
0
0
0
0
0
0
0
0
0
0
0
0
0
0
0

\begin{tabular}{|c|c|c|c|}
\hline 0 & 0 & 0 & 0 \\
\hline 0 & 0 & 0 & 0 \\
\hline 0 & 0 & 0 & 1 \\
\hline 0 & 0 & 0 & 0 \\
\hline 0 & 0 & 0 & 1 \\
\hline 0 & 0 & 0 & 0 \\
\hline 0 & 0 & 0 & 0 \\
\hline 0 & 0 & 0 & 0 \\
\hline 0 & 5 & 0 & 0 \\
\hline 3 & 11 & 0 & 0 \\
\hline 0 & 0 & 0 & 0 \\
\hline 0 & 0 & 0 & 0 \\
\hline 0 & 0 & 0 & 0 \\
\hline 55 & 22 & 21 & 19 \\
\hline 3 & 3 & 1 & 0 \\
\hline 2368 & 9 & 10 & 24 \\
\hline 31 & 3 & 124 & 15 \\
\hline 0 & 0 & 0 & 0 \\
\hline 0 & 0 & 1 & 0 \\
\hline 0 & 0 & 0 & 1 \\
\hline 0 & 0 & 0 & 8 \\
\hline 0 & 0 & 0 & 0 \\
\hline 0 & 0 & 0 & 0 \\
\hline 0 & 0 & 0 & 0 \\
\hline 0 & 0 & 0 & 0 \\
\hline 0 & 0 & 0 & 0 \\
\hline 0 & 0 & 0 & 0 \\
\hline 0 & 0 & 0 & 0 \\
\hline 0 & 0 & 0 & 0 \\
\hline 0 & 0 & 0 & 0 \\
\hline 0 & 1 & 0 & 0 \\
\hline 0 & 0 & 0 & 1 \\
\hline 0 & 0 & 0 & 0 \\
\hline 0 & 0 & 0 & 1 \\
\hline 0 & 0 & 0 & 1 \\
\hline 1 & 0 & 0 & 0 \\
\hline 0 & 0 & 0 & 0 \\
\hline 0 & 0 & 0 & 0 \\
\hline 0 & 1 & 0 & 0 \\
\hline 0 & 2 & 0 & 0 \\
\hline 0 & 1 & 0 & 0 \\
\hline
\end{tabular}

Mollusca

Unio sp.

Anodonta cygnea

Pisidium sp.

Margaritifera

margaritifera 
Annex 1. (Continuation.)

Taxon

M1006 M1009 M1016 M1019 M2006 M2009 M2016 M2019 M3006 M3009 M3016 М3019

M4006 M4009 M4016 M4019

\begin{tabular}{|c|c|c|c|c|c|c|c|c|c|c|c|c|c|c|c|c|}
\hline Sphaerim sp. & 0 & 0 & 0 & 1 & 0 & 0 & 0 & 0 & 0 & 0 & 0 & 1 & 0 & 0 & 0 & 0 \\
\hline Pisidium casertanum & 0 & 0 & 0 & 0 & 0 & 0 & 0 & 0 & 0 & 1 & 0 & 0 & 0 & 1 & 0 & 0 \\
\hline Ferrissia wautieri & 0 & 0 & 0 & 0 & 5 & 0 & 0 & 10 & 0 & 0 & 0 & 0 & 0 & 1 & 0 & 1 \\
\hline Bithynia tentaculata & 0 & 0 & 0 & 0 & 3 & 0 & 0 & 0 & 7 & 1 & 0 & 0 & 0 & 0 & 0 & 0 \\
\hline Physella acuta & 0 & 0 & 0 & 0 & 36 & 5 & 7 & 54 & 2 & 0 & 19 & 64 & 38 & 193 & 0 & 177 \\
\hline Gyraulus crista & 0 & 0 & 0 & 0 & 0 & 0 & 0 & 59 & 0 & 0 & 0 & 0 & 0 & 0 & 0 & 0 \\
\hline Gyraulus sp. & 0 & 0 & 0 & 0 & 5 & 2 & 0 & 0 & 0 & 0 & 0 & 0 & 18 & 599 & 0 & 0 \\
\hline Lymnaea peregra & 0 & 1 & 0 & 0 & 1 & 0 & 0 & 0 & 0 & 0 & 0 & 0 & 1 & 2 & 0 & 0 \\
\hline Zonitoides nitidus & 0 & 0 & 0 & 0 & 0 & 0 & 0 & 0 & 0 & 1 & 0 & 0 & 0 & 1 & 0 & 0 \\
\hline Bythinella sp. & 0 & 0 & 0 & 0 & 0 & 0 & 0 & 0 & 0 & 0 & 0 & 0 & 0 & 9 & 0 & 0 \\
\hline Ancylus fluviatilis & 6 & 4 & 0 & 0 & 5 & 0 & 0 & 2 & 0 & 0 & 0 & 0 & 0 & 0 & 0 & 0 \\
\hline Potamopyrgus jenkinsi & 4 & 0 & 0 & 0 & 401 & 1 & 37 & 9 & 0 & 0 & 10 & 4 & 0 & 0 & 0 & 0 \\
\hline Oxylom elegans & 1 & 0 & 0 & 0 & 3 & 0 & 0 & 12 & 0 & 0 & 0 & 14 & 0 & 55 & 0 & 60 \\
\hline
\end{tabular}

Oligoqueta

Eiseniella tetraedra

$\begin{array}{llllllllllll}\text { Enchytraeidae gen. sp. } & 0 & 0 & 0 & 0 & 0 & 0 & 0 & 0 & 0 & 0 & 0\end{array}$

$\begin{array}{llllllllllllll}\text { Lumbricidae gen. sp. } & 0 & 0 & 0 & 1 & 0 & 0 & 0 & 0 & 0 & 0 & 0\end{array}$

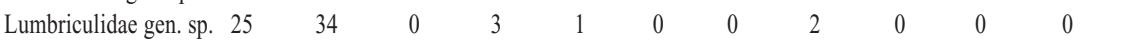

$\begin{array}{llllllllllll}\text { Tubificidae gen. sp. } & 1 & 0 & 0 & 0 & 0 & 0 & 0 & 0 & 0 & 0 & 0\end{array}$

Branchiura sowerbyi

Naididae gen. sp.

Colembola

Sminthuridae gen. sp.

Poduridae gen. sp.

Isotomidae gen. sp.

Coleoptera

Rhantus sp.

Limnius sp.

Laccophilus sp.

Stenelmis canaliculata 0

Dryops sp.

Hydaticus sp.

Copelatus sp.

Potamophilus acuminatus

Oulimnius sp.

Oulimnius troglodytes

Curcullonidae gen. sp. 0

Hydrous sp.

Enochrus sp.

Laccobius sp.

Helophorus sp.

Hydrobius sp.

Hydraena sp.

Guignotus pusillus

Helochares sp.

Agabus sp.

Berosus sp.

Bidessus pusillus

Bidessus sp.

Meladema coriacea

$\begin{array}{ccccccccccccccc}0 & 1 & 1 & 12 & 14 & 0 & 3300 & 0 & 0 & 3 & 2 & 299 & 13 & 7 & 2 \\ 0 & 0 & 0 & 0 & 0 & 0 & 0 & 0 & 0 & 0 & 0 & 0 & 0 & 0 & 2 \\ 0 & 77 & 207 & 0 & 0 & 0 & 1 & 0 & 0 & 0 & 0 & 1 & 0 & 1 & 0\end{array}$

$\begin{array}{llll}0 & 0 & 0 & 0 \\ 0 & 0 & 0 & 2 \\ 0 & 0 & 0 & 0 \\ 0 & 1 & 0 & 5 \\ 1 & 0 & 0 & 0 \\ 0 & 0 & 0 & 0 \\ 0 & 0 & 0 & 0\end{array}$

(1)


Annex 1. (Continuation.)

Taxon

M1006 M1009 M1016 M1019 M2006 M2009 M2016 M2019 M3006 M3009 M3016 M3019 M4006 M4009 M4016 M4019

\section{Trichoptera}

Ecnomus sp.

Hydropsyche sp.

Ceraclea sp.

Pseudoneuroclipsis

lusitanicus

Polycentropus sp.

Plectrocnemia sp.

Mystacides azurea

Oecetis testacea

Chimarra marginata

Lype auripilis

Hydroptila sp.

Diplectrona felix

Hydropsyche lobata

Padoniella vandeli

Tinodes waeneri

Psychomyia sp.

Gomphus pulchellus

Gomphus simillimus

Odonata

Calopteryx virgo

Platicnemis

latipes/acutipennis

Ischnura graellsi

Trithemis sp.

Pyrrhosoma nymphula

Coenagrion puella

Corduliidae gen. sp.

Coenagrion mercuriale

Calopteryx sp.

Platicnemis sp.

Ischnura elegans

Boyeria irene

$\begin{array}{rrrrrrrrrrrr}0 & 0 & 0 & 0 & 0 & 0 & 0 & 1 & 0 & 0 & 0 & 11 \\ 1 & 2 & 0 & 0 & 74 & 29 & 20 & 162 & 0 & 0 & 2 & 0 \\ 1 & 0 & 0 & 0 & 9 & 1 & 6 & 0 & 0 & 0 & 8 & 0 \\ 1 & 0 & 0 & 0 & 0 & 0 & 0 & 0 & 0 & 0 & 0 & 0\end{array}$

$\begin{array}{llll}0 & 0 & 0 & 0 \\ 0 & 0 & 0 & 0 \\ 0 & 0 & 1 & 0 \\ 0 & 0 & 0 & 0\end{array}$

$\begin{array}{rrrrrrrr}3 & 3 & 0 & 0 & 1 & 0 & 2 & 0 \\ 1 & 1 & 0 & 0 & 0 & 0 & 0 & 0 \\ 0 & 1 & 0 & 0 & 4 & 1 & 0 & 1 \\ 0 & 0 & 0 & 0 & 1 & 0 & 0 & 0 \\ 0 & 0 & 0 & 0 & 1 & 0 & 0 & 1 \\ 0 & 0 & 0 & 0 & 1 & 0 & 0 & 0 \\ 0 & 0 & 0 & 0 & 1 & 1 & 0 & 0 \\ 0 & 0 & 0 & 0 & 0 & 0 & 0 & 23 \\ 0 & 4 & 0 & 1 & 21 & 4 & 35 & 123 \\ 0 & 1 & 0 & 0 & 0 & 0 & 0 & 0 \\ 0 & 1 & 0 & 0 & 0 & 0 & 0 & 0 \\ 0 & 0 & 1 & 0 & 0 & 0 & 0 & 0 \\ 0 & 0 & 0 & 0 & 0 & 0 & 0 & 0 \\ 1 & 1 & 0 & 0 & 0 & 0 & 0 & 0\end{array}$

$\begin{array}{ll}0 & 0 \\ 0 & 0 \\ 0 & 0 \\ 0 & 0 \\ 0 & 0 \\ 0 & 0 \\ 0 & 0 \\ 0 & 0 \\ 0 & 0 \\ 0 & 0 \\ 0 & 0 \\ 0 & 0 \\ 0 & 0 \\ 0 & 0\end{array}$

0
0
0
0
0
0
0
0
1
0
0
0
1
0

0
0
0
0
0
0
0
0
0
0
0
0
0
0

$\begin{array}{llll}0 & 0 & 0 & 0 \\ 0 & 0 & 0 & 0 \\ 0 & 0 & 0 & 0 \\ 0 & 0 & 0 & 0 \\ 0 & 0 & 0 & 0 \\ 0 & 0 & 0 & 0 \\ 0 & 0 & 0 & 0 \\ 0 & 0 & 0 & 0 \\ 0 & 0 & 0 & 0 \\ 0 & 0 & 0 & 0 \\ 0 & 0 & 0 & 0 \\ 0 & 1 & 0 & 0 \\ 0 & 0 & 0 & 0 \\ 0 & 0 & 0 & 0\end{array}$

Crustacea

Atyaephyra desmarestii 28

Bragasellus cortesii

Procambarus clarkii

$\begin{array}{lll}0 & 2 & 0 \\ 0 & 0 & 0\end{array}$

$\begin{array}{lllllllllllll}0 & 1 & 1 & 0 & 1 & 0 & 0 & 0 & 0 & 0 & 1 & 0 & 0 \\ 0 & 1 & 0 & 0 & 0 & 2 & 0 & 0 & 0 & 1 & 2 & 0 & 0\end{array}$

\section{Ephemeroptera}

Caenis luctuosa

Baetis rhodani

Baetis maurus

Choroterpes salamannai

Baetis fuscatus

Heptageniidae gen. sp.

Cloeon dipterum

Cloeon simile

Ecdyonurus venosus

Ephoron virgo

Baetis scambus

$\begin{array}{lllllll}0 & 0 & 0 & 0 & 3 & 0 & 0 \\ 0 & 0 & 0 & 0 & 0 & 0 & 0 \\ 0 & 0 & 0 & 0 & 0 & 0 & 0 \\ 0 & 0 & 0 & 0 & 0 & 0 & 0 \\ 0 & 0 & 0 & 0 & 0 & 0 & 0 \\ 0 & 0 & 0 & 0 & 0 & 0 & 0 \\ 0 & 2 & 0 & 0 & 0 & 0 & 0 \\ 0 & 2 & 0 & 0 & 0 & 0 & 0 \\ 0 & 0 & 0 & 0 & 0 & 3 & 0 \\ 0 & 0 & 0 & 0 & 0 & 0 & 0\end{array}$

$\begin{array}{rrrrr}8 & 0 & 0 & 0 & 0 \\ 0 & 0 & 0 & 0 & 0 \\ 0 & 0 & 0 & 0 & 1 \\ 49 & 0 & 0 & 0 & 0 \\ 1 & 0 & 0 & 0 & 0 \\ 9 & 0 & 0 & 0 & 0 \\ 0 & 0 & 0 & 0 & 0 \\ 0 & 0 & 0 & 0 & 0 \\ 0 & 0 & 0 & 0 & 0 \\ 0 & 0 & 0 & 0 & 0\end{array}$

$\begin{array}{llll}0 & 0 & 0 & 0 \\ 1 & 0 & 0 & 0 \\ 0 & 0 & 0 & 0 \\ 1 & 3 & 0 & 0 \\ 0 & 0 & 0 & 0 \\ 4 & 0 & 0 & 0 \\ 0 & 0 & 0 & 0 \\ 0 & 0 & 0 & 0 \\ 0 & 0 & 0 & 0 \\ 0 & 1 & 0 & 0\end{array}$


Annex 1. (Continuation.)

Taxon

M1006 M1009 M1016 M1019 M2006 M2009 M2016 M2019 M3006 M3009 M3016 M3019

M4006 M4009 M4016 M4019

\begin{tabular}{|c|c|c|c|c|c|c|c|c|c|c|c|c|c|c|c|c|}
\hline Centroptilum luteolum & 0 & 0 & 0 & 0 & 0 & 0 & 0 & 0 & 0 & 1 & 0 & 0 & 0 & 0 & 0 & 0 \\
\hline $\begin{array}{l}\text { Pseudocentroptilum } \\
\text { pennulatum }\end{array}$ & 0 & 0 & 0 & 0 & 0 & 0 & 0 & 0 & 0 & 1 & 0 & 0 & 0 & 0 & 0 & 0 \\
\hline \multicolumn{17}{|l|}{ Triclades } \\
\hline Dugesia polychroa & 0 & 0 & 0 & 0 & 10 & 0 & 0 & 0 & 0 & 0 & 0 & 0 & 0 & 0 & 0 & 0 \\
\hline Planaria torva & 0 & 0 & 0 & 0 & 40 & 0 & 0 & 0 & 0 & 0 & 0 & 0 & 0 & 0 & 0 & 0 \\
\hline Dugesia lugubris & 0 & 0 & 0 & 0 & 21 & 0 & 0 & 0 & 0 & 0 & 0 & 0 & 0 & 0 & 0 & 0 \\
\hline
\end{tabular}

\section{Heteroptera}

\begin{tabular}{|c|c|c|c|c|c|c|c|c|c|c|c|c|c|c|c|c|}
\hline Aquarius najas/cinereus & & 0 & 0 & 0 & 0 & 0 & 0 & 32 & 0 & 0 & 0 & 0 & 0 & 0 & 0 & 0 \\
\hline Aquarius najas & 0 & 0 & 0 & 0 & 0 & 7 & 2 & 2 & 0 & 0 & 8 & 3 & 0 & 0 & 0 & 0 \\
\hline Aquarius cinereus & 0 & 0 & 0 & 0 & 1 & 2 & 1 & 10 & 0 & 0 & 0 & 156 & 0 & 0 & 0 & 0 \\
\hline Gerridae gen. sp. & 0 & 0 & 0 & 0 & 2 & 2 & 0 & 0 & 0 & 0 & 6 & 0 & 1 & 0 & 0 & 0 \\
\hline Micronecta minuscula & 0 & 0 & 0 & 2 & 0 & 0 & 0 & 65 & 0 & 0 & 1 & 161 & 0 & 0 & 4 & 19 \\
\hline Micronecta scholtzi & 0 & 0 & 0 & 0 & 8 & 0 & 0 & 16 & 0 & 0 & 7 & 198 & 8 & 0 & 7 & 211 \\
\hline Micronecta sp. & 0 & 0 & 0 & 0 & 0 & 0 & 0 & 7 & 0 & 0 & 0 & 145 & 0 & 0 & 0 & 39 \\
\hline Naucoris maculatus & 0 & 0 & 0 & 0 & 4 & 0 & 0 & 0 & 0 & 0 & 0 & 0 & 2 & 0 & 0 & 0 \\
\hline Ochterus marginatus & 0 & 0 & 0 & 0 & 0 & 0 & 0 & 0 & 0 & 0 & 0 & 0 & 3 & 0 & 0 & 0 \\
\hline Corixidae gen. sp. & 0 & 0 & 0 & 0 & 0 & 0 & 0 & 0 & 0 & 0 & 0 & 0 & 6 & 0 & 0 & 0 \\
\hline Sigara sp. & 0 & 0 & 0 & 0 & 0 & 0 & 0 & 0 & 0 & 0 & 0 & 0 & 10 & 0 & 0 & 0 \\
\hline Sigara semistriata & 0 & 0 & 0 & 0 & 0 & 0 & 0 & 0 & 0 & 1 & 0 & 0 & 0 & 0 & 0 & 6 \\
\hline Mesovelia vittigera & 0 & 0 & 0 & 0 & 0 & 0 & 0 & 2 & 0 & 0 & 0 & 0 & 0 & 0 & 0 & 2 \\
\hline Hydrometra stagnorum & 0 & 1 & 0 & 0 & 0 & 0 & 0 & 5 & 0 & 0 & 0 & 0 & 1 & 0 & 0 & 0 \\
\hline Notonectidae gen. sp. & 0 & 0 & 0 & 0 & 0 & 0 & 0 & 0 & 0 & 0 & 0 & 0 & 1 & 0 & 0 & 0 \\
\hline Gerris lateralis & 0 & 1 & 0 & 0 & 0 & 0 & 297 & 0 & 0 & 0 & 0 & 0 & 0 & 0 & 0 & 1 \\
\hline Nepa cinerea & 0 & 0 & 0 & 0 & 0 & 1 & 0 & 0 & 0 & 0 & 0 & 0 & 0 & 0 & 1 & 0 \\
\hline Gerris thoracicus & 0 & 0 & 0 & 0 & 0 & 0 & 0 & 1 & 0 & 1 & 0 & 0 & 0 & 0 & 0 & 0 \\
\hline Hydrometra stagnorum & 0 & 0 & 0 & 0 & 0 & 0 & 0 & 0 & 0 & 0 & 0 & 0 & 0 & 1 & 0 & 0 \\
\hline
\end{tabular}

\section{Plecoptera}

Leuctra

Leuctra fusca

Leuctra sp.

Leuctra geniculata $\quad 0 \quad 0 \quad 000$

Perlodes microcephala 0

Acheta

\begin{tabular}{|c|c|c|c|c|c|c|c|c|c|c|c|c|c|c|c|}
\hline Helobdella stagnalis & 0 & 0 & 0 & 0 & 0 & 1 & 0 & 0 & 0 & 0 & 0 & 0 & 0 & 0 & 0 \\
\hline Erpobdellidae gen. sp. & 0 & 0 & 0 & 0 & 0 & 0 & 0 & 0 & 0 & 0 & 1 & 0 & 0 & 0 & 0 \\
\hline Erpobdella monostriata & 0 & 0 & 0 & 0 & 0 & 0 & 0 & 2 & 0 & 0 & 0 & 1 & 0 & 0 & 0 \\
\hline Glossiphonia & 0 & 0 & 0 & 0 & 0 & 0 & 0 & 0 & 0 & 0 & 2 & 0 & 0 & 0 & 0 \\
\hline
\end{tabular}

